\title{
Magnesium Metabolism, Vitamin D and Interleukins in Cardiovascular Disease
}

Kisters $\mathbf{K}^{1^{*}}$, Gremmler $\mathbf{B}^{2}$, Gröber $\mathrm{U}^{3}$ and Tokmak $\mathrm{F}^{1^{*}}$

${ }^{1}$ Med Clinic I, St. Anna Hospital, Hospitalstr. 19, Herne 44649, Germany

${ }^{2}$ Department of Cardiology, Bottrop, Germany

${ }^{3}$ Academy for Micronutrients, Essen, Germany

\begin{abstract}
A magnesium deficiency is known to be involved in the pathogenesis of cardiovascular diseases. In patients with essential hypertension intima media thickness is increased in about $70 \%$ (ELSA Study). In our study, we investigated 21 patients (10 female, 11 male, average age $56.3 \pm 6.6$ years) with untreated essential hypertension (grades I and II according to WHO guidelines). All patients had a hypomagnesiaemia in serum $(1.57 \pm 0.11 \mathrm{mg} \%)$. In all patients we found a significant increase in intima media thickness of arteria carotis communis $(0.97 \pm 0.08 \mathrm{~mm})(\mathrm{r}=-0.869$, $p<0.0001)$. The results show that a magnesium deficiency in patients with essential hypertension may be of special pathogenetic importance. In addition, the role of magnesium deficiency in the development of arteriosclerosis has to be discussed. Furthermore, we demonstrated a connection between magnesium deficiency and an increased intima media thickness. In this context, calcium antagonist therapy or magnesium supplementation may be of advantage when treating intima media thickness in hypertension.
\end{abstract}

In addition in essential hypertensives with diabetes mellitus type llb showing lowered magnesium $(1.72 \pm 0.08 \mathrm{mg} /$ $\mathrm{dl})$ and vitamin $\mathrm{D}(9.55 \pm 4.74 \mathrm{ng} / \mathrm{ml})$ levels interleukine 6 concentrations were $8.57 \pm 4.14 \mathrm{pg} / \mathrm{ml}(\mathrm{p}<0.01 \mathrm{vs}$. controls $)$ being a risk factor for metabolic disorder, e. g. arteriosclerosis.

Keywords: Magnesium; Cardiovascular disease; Metabolism; Arteriosclerosis; Vitamin D

\section{Introduction}

Cardiovascular epidemiology has expanded from studies focusing only on cardiovascular risk factors to include research on causes and consequences of atherosclerosis and associated arterial wall abnormalities. In a large number of studies, techniques have been used that enable non-invasive assessment of vascular characteristics to study early functional and structural wall changes. Examples of these measurements are coronary artery calcium levels, arterial stiffness, brachial endothelial function, aortic augmentation index (Aix) and carotid intima-media thickness (CIMT). One of the reasons for an increased attention on these indicators is that the availability of adequate noninvasively assessed measurements of functional and structural arterial characteristics allows for studies among children, adolescents and young adults. Such studies may greatly enhance our insight in causes, development and pathophysiological mechanisms of cardiovascular disease. Furthermore, these measurement extend research into middle aged and elderly subjects who are yet free from symptomatic cardiovascular disease [1].

Several new studies have focused on the role of CIMT in predicting future vascular events [1,2].

Studies performed in the general population consistently showed a gradual graded increase in risk with increased CIMT. The magnitude of association differed somewhat by age but in general was remarkably similar across studies.

CIMT may help, in addition to established risk factors, in identifying those individuals that will suffer from cerebrovascular and coronary heart disease [3-5].

In this context changes in magnesium metabolism have been implicated in the pathogenesis of hypertension [6-28]. Therefore it was of interest to study magnesium deficient patients with essential hypertension concerning CIMT and arteriosclerosis and vitamin D disorder.

\section{Subjects and Methods}

\section{Subjects}

21 patients were studied, 11 male and 10 female. The average age was $56.3 \pm 6.6$ years. All patients had a normal renal function (serumcreatinine $0.85 \pm 0.4 \mathrm{mg} \%$ ). In all patients cholesterol and triglyceride concentrations were significantly increased.

In a second additional study 11 different hypertensive patients with diabetes mellitus type IIb with magnesium loss and lowered vitamin D status were investigated concerning interleukine 6 levels.

All patients were informed about the aim of the study according to the Helsinki Charter and had given written consent at the time of investigation.

\section{Methods}

The analysis of serum magnesium concentrations was performed by a Hitachi analyser. Measurements of intima media thickness were performed in the arteria carotis communis with a GE apparatus Vivid 5 , Solingen, Germany.

*Corresponding author: Kisters K, Med Clinic I, St. Anna Hospital, Hospitalstr. 19, Herne 44649, Germany, Tel: 4923259862100; E-mail: klaus.kisters@elisabethgruppe.de

Received May 18, 2016; Accepted June 16, 2016; Published June 20, 2016

Citation: Kisters K, Gremmler B, Gröber U, Tokmak F (2016) Magnesium Metabolism, Vitamin D and Interleukins in Cardiovascular Disease. Metabolomics 6: 177. doi:10.4172/2153-0769.1000177

Copyright: ( 2016 Kisters K, et al. This is an open-access article distributed under the terms of the Creative Commons Attribution License, which permits unrestricted use, distribution, and reproduction in any medium, provided the original author and source are credited. 
Vitamin D and interleukine 6 measurements were performed in serum by a Hitachi analyser, too.

\section{Statistical Analysis}

Statistical analyses was performed using ANOVA.

The results are given as means $\pm \mathrm{SD}$, a $\mathrm{p}<0.05$ was considered significant. The reported $\mathrm{p}$ values are two-tailed.

\section{Results}

The mean serum magnesium concentration was $1.57 \pm 0.11 \mathrm{mg} / \mathrm{dl}$ (normal range for serum magnesium: $1.70-2.55 \mathrm{mg} / \mathrm{dl}$ ). IMT (in $\mathrm{mm}$ ) was measured $0.97 \pm 0.8$. The normal range is known to be below 0.7 $\mathrm{mm}$. The correlation coefficient $\mathrm{r}=-0.869, \mathrm{p}<0.0001$.

In hypertensive diabetics type II serum magnesium levels were 1.72 $\pm 0.08 \mathrm{mg} / \mathrm{dl}$, which was in the lower normal range or below. Interleukine 6 concentrations were $8.57 \pm 4.14 \mathrm{pg} / \mathrm{ml}$, being significantly increased as compared to controls $(\mathrm{p}<0.01)$.

Vitamin D levels were significantly decreased in patients with 9.55 $\pm 4.74 \mathrm{ng} / \mathrm{ml}(\mathrm{p}<0.01)$ (normal range: $>20 \mathrm{ng} / \mathrm{ml}$ ).

The vitamin $\mathrm{D} /$ magnesium ratio was $5.59 \pm 2.87$ in 11 hypertensive diabetics type IIb, being lower than values of normal range.

\section{Discussion}

A role for lowered magnesium concentrations in vascular tone has been postulated in essential hypertension [6-28].

In essential hypertensives, Resnick et al. $[29,30]$ found decreased intracellular free $\mathrm{Mg}^{++}$concentrations in red blood cells as estimated by nuclear magnetic resonance spectroscopy $(29,30)$. Analogous findings were reported in red blood cells from spontaneously hypertensive rats [11-16,31].

On the basis of experimental data, the theoretical mechanisms underlying the $\mathrm{Mg}^{++}$-induced vasodilation may be: (a) a modification of the response to vasopressor hormones, and (b) an interaction with cellular $\mathrm{Ca}^{++}$handling [32]. These possible mechanisms are supported by 3 lines of recent evidence. First, the extracellular $\mathrm{Mg}^{++}$concentration can influence $\mathrm{Ca}^{++}$metabolism of vascular smooth muscle by changing the $\mathrm{Ca}^{++}$influx through the plasma membrane. Recently, in single myocytes from frog ventricle, the site of interaction between $\mathrm{Mg}^{++}$ and $\mathrm{Ca}^{++}$inward current that is dependent on phosphorylation by cyclic adenosine monophosphatase [33]. Second. Changes in the extracellular $\mathrm{Mg}^{++}$concentration induced inverse changes in the $\mathrm{Ca}^{++}$ content of vascular smooth muscle and in exchangeable $\mathrm{Ca}^{++}[34,35]$. Third, a decrease in the intracellular free $\mathrm{Mg}^{++}$concentration results in diminished membrane $\mathrm{Na}^{+}, \mathrm{K}^{+}$-adenosine triphosphatase and $\mathrm{Ca}^{++}$ ATPase activities, and, as a corollary, increased $\mathrm{Na}^{+}-\mathrm{Ca}^{++}$exchange and increased intracellular $\mathrm{Na}^{+}$and $\mathrm{Ca}^{++}$concentrations [36]. In addition a sodium magnesium antiport exists in red blood cells and in vascular smooth muscle cells [9]. TRPM (transient receptor potential channel melastin member) type 6 and 7 -channels, recently described, regulate intracellular magnesium stores, too $[37,38]$.

It is well known, that an increased intima media thickness is a marker for cardiovascular morbidity and mortality. Functional and structural arterial measurements confer an increased risk for cardiovascular disease. It has been suggested that the increase in the stiffness of the arterial wall with aging can be explained by a decrease in elastin density (or collagen) [39-45].
Calcification of arteries is a common phenomenon especially in the elderly [34].

Aortic wall calcium (and phosphorus) contents increase with age. Age linked medial calcification is associated with elastic fibers [34]. Physical factors such as increased intraluminal pressure (e.g. hypertension) that promote elastocalcionis suggested that global degeneration of the arterial wall, of stress on medial elastic fibers and lamellae are followed by fracture. As pulse pressure increases in hypertension (especially so in isolated systolic hypertension), cyclic wall stress is increased and so fracture and elastocalcinosis would be expected to occur earlier. In this context it is well documented that magnesium acts as a physiological calcium antagonist and is necessary for an intact phosphorus metabolism. As described early by our group a magnesium deficiency is involved in the pathogenesis of primary hypertension, the development of elevated pulse pressure values and as shown here in an increased intima media thickening [41,43].

In addition a negative correlation concerning magnesium loss and elevated blood lipid composition was described earlier, even by our group.

It is also of recent interest that antihypertensive drug treatment with calcium antagonist is of special benefit in avoiding intima media thickening and thereby in preventing stroke. Calcium antagonists lower blood pressure and reduce cardiovascular morbidity and mortality [4449].

In addition data presented here show decreased magnesium concentrations and vitamin D levels and increased interleukin levels in hypertensive patients with diabetes mellitus type IIb.

IL-6 plays an important role in the development of arterial stiffness and arteriosclerosis in hypertensive patients and in diabetics. The combination of both hypertension and diabetes shows even more arteriosclerotic organe damage in which IL-6 is pathophysiologically involved [28].

These findings favour the development of an increased intima media thickness and the manifestation of arteriosclerosis.

In conclusion, a vitamin $\mathrm{D}$ loss in hypertensive patients with diabetes mellitus type IIb has to be corrected immediately. Normally, the daily amount of magnesium is $300-480 \mathrm{mg}$, vitamin $\mathrm{D}$ should be given 1,000 I.E. at least [50].

\section{References}

1. Bots ML, Hoes AW, Koudstaal PJ, Hofman A, Grobbee DE (1997) Common carotid intima-media thickness and risk of stroke and myocardial infarction: the Rotterdam Study. Circulation 96: 1432-1437.

2. Salonen JT, Salonen R (1991) Ultrasonographically assessed carotid morphology and the risk of coronary heart disease. Arterioscler Thromb 11 1245-1249.

3. Zanchetti A, Bond MG, Hennig M, Neiss A, Mancia G, et al. (2002) Calcium antagonist lacidipine slowsdown progression of asymptomatic carotid atherosclerosis: principal results of the European Lacidipine Study on Atherosclerosis (ELSA), a randomised, double-blind, long-term trial. Circulation 106: 2422-2427.

4. Laurent S, Boutouyrie P, Lacolley $P$ (2005) Structural and genetic bases of arterial stiffness. Hypertension 45: 1050-1055.

5. Laurent S, Katsahian S, Fassot C, Tropeano Al, Gautier I, et al. (2003) Aortic stiffness is an independent predictor of fatal stroke in essential hypertension. Stroke 34: 1203-1206.

6. Durlach J (1988) Magnesium in clinical practice. London: John Libbey, pp: 360

7. Durlach J, Durlach V, Rayssiguier Y, Bara M, Guiet-Bara A (1992) Magnesium 
and blood pressure. II. Clinical studies. Magnes Res 5: 147-153.

8. Kisters K, Tepel M, Spieker C, Dietl KH, Barenbrock M, et al. (1997) Decreased cellular $\mathrm{Mg}^{2+}$ concentrations in a subgroup of hypertensives--cell models for the pathogenesis of primary hypertension. J Hum Hypertens 11: 367-372.

9. Kisters K, Tepel M, Spieker C, Zidek W, Barenbrock M, et al. (1998) Decreased cellular $\mathrm{Mg}^{++}$concentrations in a subgroup of hypertensives. Membrane model for the pathogenesis of primary hyprtension. Am J Hypertens 11: 1390-1393.

10. Kisters K, Barenbrock M, Louwen F, Hausberg M, Rahn KH, et al. (2000) Membrane, intracellular, and plasma magnesium and calcium concentrations in preeclampsia. Am J Hypertens 13: 765-769.

11. Kisters K, Krefting ER, Hausberg M, Kohnert K, Honig A, et al. (2000) Importance of decreased intracellular phosphate and magnesium concentrations and reduced ATPase activities in SHR. Magnes Res 13: 183-188.

12. Kisters K, Hausberg M, Kosch M (2001) Effect of oral magnesium supplemementation on blood pressure, platelet aggregation and calcium handling in deoxy corticosterone acetate-induced hypertenstion in rats. J Hypertens 1: 161-162.

13. Kisters K, Wessels F, Tokmak F, Küper H, Hausberg M, et al. (2003) Increased arterial smooth muscle cell calcium and decreased magnesium concentrations in spontaneously hypertensive rats (SHR) and in human hypertension. Trace Elem Electrolytes 21: 201.

14. Kisters K, Wessels F, Tokmak F, Krefting ER, Gremmler B, et al. (2004) Earlyonset increased calcium and decreased magnesium concentrations and an increased calcium/magnesium ratio in SHR versus WKY. Magnes Res 17: 264269.

15. Kisters K, Wessels F, Küper H, Tokmak F, Krefting ER, et al. (2004) Increased calcium and decreased magnesium concentrations and an increased calcium/ magnesium ratio in spontaneously hypertensive rats versus Wistar-Kyoto rats: relation to arteriosclerosis. Am J Hypertens 17: 59-62.

16. Kisters K, Gremmler B, Hausberg M (2005) Pulse pressure, plasma magnesium status, and antihypertensive therapy. Am J Hypertens 18: 1136.

17. Kisters K, Gremmler B, Hausberg M (2005) Magnesium and arterial stiffness. Hypertension (Epub)

18. Kisters K, Hoffmann O, Hausberg M, Funke C, Kozianka J, et al. (2005) Magnesium und Pulsdruck bei Hypertonie. Nieren- und Hochdruckkrh 10: 455457.

19. Kisters K, Tokmak F, Gremmler B, Kosch M, Hausberg M (2005) Increased calcium/magnesium ratio in young and old spontaneously hypertensive rats: Pathogenetic factor in the development of hypertension and vascular fibrosis. Am J Hypertens 18: 295.

20. Kisters K, Hoffmann O, Gremmler B, Hausberg M (2005) Plasma magnesium defiency ist correlated to pulse pressure values in essential hypertensioninfluence of a metabolic syndrome. Am J Hypertens 18: 215A

21. Kisters K, Wessels F, Gremmler B, Quang Nguyen M, Kosch M, et al. (2005) Early onset of decreased intracellular magnesium and phosphate concentration in smooth muscle cells auf SHR. Am J Hypertens 23: 233.

22. Kisters K, Hoffmann O, Hausberg M, Quang Nguyen, Micke O, et al. (2005) Plasma magnesium status and pulse pressure in essential hypertension. Trace Elem Electrolyt 22: 254-256.

23. Kisters K, Wessels F, Krefting ER, Gremmler B, Quang Nguyen M, et al. (2005) Early onset of a decreased intracellular magnesium and phosphate concentration in smooth muscle cells of SHR. Magnes Res 18: 207-213.

24. Kisters K, Gremmler B, Hausberg M (2006) Preventing pregnancy-induced hypertension: the role of calcium and magnesium. J Hypertens 24: 201.

25. Kisters K, Gremmler B, Kozianka J, Hausberg M (2006 ) Magnesium deficiency and diabetes mellitus. Clin Nephrol 65: 77-78.

26. Kisters K, Gröber U (2013) Magnesium in health and disease. Plant and Soil. E-pub.

27. Rayssiguier Y, Mbega JD, Durlach V, Gueux E, Durlach J, et al. (1992) Magnesium and blood pressure. I. Animal studies. Magnes Res 5: 139-146.

28. Gröber U, Schmidt J, Kisters K (2015) Magnesium in Prevention and Therapy. Nutrients 7: 8199-8226.

29. Resnick LM, Laragh JH, Sealey JE, Alderman MH (1983) Divalent cations in essential hypertension. Relations between serum ionized calcium, magnesium and plasma renin activity. N Engl J Med 309: 888-891.

30. Resnick LM, Laragh JH, Sealey JE, Aldermann MH (1983) Divalent cations in essential hypertension: relations between serum ionized calcium, magnesium, and plasma renin activity. N Engl J Med 309: 888-891.

31. Resnick LM, Gupta RK, Laragh JH (1984) Intracellular free magnesium in erythrocytes of essential hypertension: relation to blood pressure and serum divalent cations. Proc Natl Acad Sci U S A 81: 6511-6515.

32. Altura BM, Altura T, Carella A (1983) $\mathrm{Mg}^{++}$deficiency-induced spasms of umbilical vessels: realtion to preeclampsia, hypertension, growth retardation. Science 221: $376-378$.

33. White RE, Hartzell HC (1988) Effects of intracellular free magnesium on calcium current in isolated cardiac myocytes. Science 239: 778-780.

34. Palatý V (1971) Distribution of magnesium in the arterial wall. J Physiol 218: 353-368.

35. Goldstein S, Zsoter TT (1978) The effect of magnesium on the response of smooth muscle to 5-hydroxytryptamine. Br J Pharmacol 62: 507-514.

36. Alvarez-Leefmans FJ, Giraldez F, Gamiño SM (1987) Intracellular free magnesium in excitable cells: its measurement and its biologic significance. Can J Physiol Pharmacol 65: 915-925.

37. Touyz RM, Milne FJ (1999) Magnesium supplementation attenuates, but does not prevent, development of hypertension in spontaneously hypertensive rats. Am J Hypertens 12: 757-765.

38. Touyz RM, Yao G (2004) Presence of functionally active $\mathrm{Mg}^{++}$uptake channels TRPM6 and TRPM7 in vascular smooth muscle cells from WKY and SHRdifferential regulation bei aldosterone and angiotensin II. Am J Hypertens 5: 176.

39. Boutouyrie P, Tropeano AI, Asmar R, Gautier I, Benetos A, et al. (2002) Aortic stiffness is an independent predictor of primary coronary events in hypertensive patients: a longitudinal study. Hypertension 39: 10-15.

40. Zimlichman R, Shargorodsky M, Boaz M, Duprez D, Rahn KH, et al. (2005) Determination of arterial compliance using blood pressare waveform analysis with the CR-2000 systems: Reliability, repeatability, and establishment of normal values for healthy European population-the seven European sites study (SESS). Am J Hypertens 18: 65-71.

41. Atkinson J (2006) Elastin, calcium and the arterial wall. In Arterial Stiffness in Hyertension. In: (Safar ME, O’Rourke MF eds.), Elsevier 23.

42. Dijk JM, Bots ML (2006) Carotid intima-media thixkness and arterial stiffness: indicators of a cardiovascular risk and modifications by treatment. In: (Safa ME, O'Rourke MF eds.), In Arterial Stiffness in Hyertension. Elsevier, p: 23.

43. Hodis HN, Mack WJ, LaBree L, Selzer RH, Liu CR, et al. (1998) The role of carotid arterial intima-media thickness in predicting clinical coronary events. Ann Intern Med 128: 262-269.

44. Asmar R (2006) Long-term effects of converting enzyme inhibitors, calcium antagonist and ?-blocking agents on peripheral and central arteries. In Arterial Stiffness in Hyertension. In: Safar ME, O'Rourke MF (eds.), Elsevier.

45. O'Rourke MF, Franklin SS (2006) Arterial stiffness: reflections on the arterial pulse. Eur Heart J 27: 2497-2498.

46. Dijk JM, van der Graaf Y, Bots ML, Gobbee DE, and Algra A (2006) Carotid intima-media thickness and the risk of new vascular events in patients with manifest atherosclerotic disease: The Smart study. European Heart Jounal 27: 1971-1978.

47. Turnbull F; Blood Pressure Lowering Treatment Trialists' Collaboration (2003) Effects of different blood-pressure-lowering regimens on major cardiovascular events: results of prospectively-designed overviews of randomised trials. Lancet 362: 1527-1535.

48. Staessen JA, Li Y, Thijs L, Wang JG (2006) Antihypertensive drug treatment and cardiovascular prevention: an update including the 2003-2004 secondary prevention trials. In: Safar ME, O'Rourke MF (eds.), In Arterial Stiffness in Hyertension, p: 23

49. Rock E, Astier C, Lab C, Malpuech C, Nowacki W, et al. (1995) Magnesium deficiency in rats induces a rise in plasma nitric oxide. Magnes Res 8: 237-242.

50. Gröber U, Spitz J, Reichrath J, Kisters K, Holick MF (2013) Vitamin D: Update 2013: From rickets prophylaxis to general preventive healthcare. Dermatoendocrinol 5: 331-347. 